\title{
Modeling of Economic Security of the Enterprise at Change of Investment Maintenance
}

\author{
SVITLANA BONDARENKO ${ }^{1}$, HALYNA TKACHUK ${ }^{2}$, IRYNA KLOCHAN ${ }^{3}$, ANDREY MOKHNENKO ${ }^{4}$, \\ IRYNA LIGANENKO ${ }^{5}$, VASYL MARTYNENKO ${ }^{6}$ \\ ${ }^{1}$ Department of Hotel, Restaurant and Tourist Business, KYIV NATIONAL UNIVERSITY OF CULTURE AND ARTS, \\ UKRAINE, E-mail: lana.bond@ukr.net, ORCID: http://orcid.org/0000-0002-4816-4579 \\ ${ }^{2}$ Department of Accounting and Auditing, ODESSA NATIONAL ACADEMY OF FOOD TECHNOLOGIES, UKRAINE, \\ E-mail: talla2007@ukr.net, ORCID: http://orcid.org/0000-0002-4816-4579 \\ ${ }^{3}$ Department of Economic Cybernetics and Mathematical Modeling, MYKOLAIV NATIONAL AGRARIAN \\ UNIVERSITY, UKRAINE, E-mail: ivclochan@gmail.com, ORCID: http://orcid.org/0000-0002-4816-4579 \\ ${ }^{4}$ Department of Finance, Accounting and Entrepreneurship, KHERSON STATE UNIVERSITY, UKRAINE, \\ E-mail: mohnenkoas@gmail.com, ORCID: http://orcid.org/0000-0002-4816-4579 \\ ${ }^{5}$ Deputy Director for Educational and Methodical Work, INTERREGIONAL ACADEMY OF PERSONNEL \\ MANAGEMENT, UKRAINE, E-mail: ir-vit-lig@ukr.net, ORCID: http://orcid.org/0000-0002-4816-4579 \\ ${ }^{6}$ Department of Economics and Entrepreneurship, NATIONAL TECHNICAL UNIVERSITY OF UKRAINE "IGOR \\ SIKORSKY KYIV POLYTECHNIC UNIVERSITY", UKRAINE, E-mail: 5Martynenko@ukr.net, \\ ORCID: http://orcid.org/0000-0002-4816-4579
}

\begin{abstract}
The purpose of this study is formation of tools for forecasting the economic security of the enterprise by modeling methods when changing investment support. The relevance of this study is due to the need to solve the problem of modernization management system of the enterprise by implementing the project management of economic security of the enterprise in the implementation of investment programs. The variant of model offered economic security of the enterprise. This model involves the implementation of the process of adaptive management, based on the definition of safe limits of longterm growth of the enterprise. It has established that the ratio of self-organization processes and managerial influences depends on the value of the self-organization coefficient. The calculated value of adaptive potential on the basis of the indicator of self-organization as the dynamic indicator of maintenance of perspective growth of the enterprise on the allocated purposes has offered. This indicator can serve as a criterion for assessing the effectiveness of the management system of the enterprise in relation to the project management of economic security of the enterprise in the implementation of investment programs of key goals of long-term growth of the enterprise.
\end{abstract}

Keywords: Economic security of the enterprise; Investments; Project management; Project risks; Investment activity of the enterprise; Self-organization.

JEL classification: C6, L2, M1

Received: April 09, 2021

Accepted: June 12, 2021 



\title{
Modelización de la Seguridad Económica de la Empresa en el Cambio de Mantenimiento de la Inversión
}

\author{
SVITLANA BONDARENKO ${ }^{1}$, HALYNA TKACHUK², IRYNA KLOCHAN ${ }^{3}$, ANDREY MOKHNENKO ${ }^{4}$, \\ IRYNA LIGANENKO ${ }^{5}$, VASYL MARTYNENKO 6 \\ ${ }^{1}$ Department of Hotel, Restaurant and Tourist Business, KYIV NATIONAL UNIVERSITY OF CULTURE AND ARTS, \\ UKRAINE, E-mail: lana.bond@ukr.net, ORCID: http://orcid.org/0000-0002-4816-4579 \\ ${ }^{2}$ Department of Accounting and Auditing, ODESSA NATIONAL ACADEMY OF FOOD TECHNOLOGIES, UKRAINE, \\ E-mail: talla2007@ukr.net, ORCID: http://orcid.org/0000-0002-4816-4579 \\ ${ }^{3}$ Department of Economic Cybernetics and Mathematical Modeling, MYKOLAIV NATIONAL AGRARIAN \\ UNIVERSITY, UKRAINE, E-mail: ivclochan@gmail.com, ORCID: http://orcid.org/0000-0002-4816-4579 \\ ${ }^{4}$ Department of Finance, Accounting and Entrepreneurship, KHERSON STATE UNIVERSITY, UKRAINE, \\ E-mail: mohnenkoas@gmail.com, ORCID: http://orcid.org/0000-0002-4816-4579 \\ ${ }^{5}$ Deputy Director for Educational and Methodical Work, INTERREGIONAL ACADEMY OF PERSONNEL \\ MANAGEMENT, UKRAINE, E-mail: ir-vit-lig@ukr.net, ORCID: http://orcid.org/0000-0002-4816-4579 \\ ${ }^{6}$ Department of Economics and Entrepreneurship, NATIONAL TECHNICAL UNIVERSITY OF UKRAINE "IGOR \\ SIKORSKY KYIV POLYTECHNIC UNIVERSITY", UKRAINE, E-mail: 5Martynenko@ukr.net, \\ ORCID: http://orcid.org/0000-0002-4816-4579
}

\section{RESUMEN}

El propósito de este estudio es la formación de herramientas para la previsión de la seguridad económica de la empresa por los métodos de modelado cuando el cambio de apoyo a la inversión. La relevancia de este estudio se debe a la necesidad de resolver el problema del sistema de gestión de la modernización de la empresa mediante la aplicación del proyecto de gestión de la seguridad económica de la empresa en la ejecución de los programas de inversión.La variante del modelo ofrecido seguridad económica de la empresa. Este modelo implica la aplicación del proceso de gestión de adaptación, basado en la definición de los límites de seguridad de crecimiento a largo plazo de la empresa. Se ha establecido que la relación de los procesos de auto-organización y las influencias de gestión depende del valor del coeficiente de auto-organización. El valor calculado del potencial de adaptación sobre la base del indicador de auto-organización como el indicador dinámico de mantenimiento de la perspectiva de crecimiento de la empresa en los fines asignados ha ofrecido. Este indicador puede servir como un criterio para evaluar la eficacia del sistema de gestión de la empresa en relación con el proyecto de gestión de la seguridad económica de la empresa en la aplicación de los programas de inversión de los objetivos clave de crecimiento a largo plazo de la empresa.

Palabras claves: Seguridad económica de la empresa; Inversiones; Gestión de proyectos; Riesgos de los proyectos; Actividad inversora de la empresa; Autoorganización.

Clasificación JEL: C6, L2, M1

Recibido: 09 de abril de 2021

Aceptado: 12 de junio de 2021 


\section{Introduction}

\section{Relevance of the topic and problem statement}

Investments are an important factor in ensuring the strategic direction of the enterprise, which has associated with specific development goals. For the normal functioning and development of the enterprise it is necessary to increase its investment attractiveness, while minimizing the risks of making the wrong decision, and work on the absorption of investment for technological development. Investment risks have characterized by a close relationship between potential threats, probabilities and uncertainty.

Software economic security of the enterprise is possible on the basis of identification and harmonization of the interests of the enterprise with the external environment, which have considered as a form of active protection of the interests of the enterprise (Kaplan \& Norton, 1996). According to the concept of acceptable risk, attention must be paid the management system of investment activities of the enterprise, as sources of investment resources are sometimes vulnerable to external and internal threats or themselves pose such threats to the economic security of the enterprise.

Provisioning process economic security of the enterprise must be consistent with the objectives and resources of a particular enterprise, which are currently available. That is, the goals, mission of the enterprise and measures to ensure the planned level of its economic security must have the same directional vectors. If this condition is met, the target orientation of the economic security management system of the enterprise will be: a) the formation of adaptive responses to threats, b) ensuring effective operation and c) high potential and pace of sustainable development.

Thus, the development of the mechanism of adaptive management of the enterprise as an open socio-economic system capable of self-organization becomes especially relevant. This will organically combine the properties of stability and, at the same time, flexibility and adaptability, which determine the ability of the system to function and develop safely (Babenko et al., 2019). The basis of such a mechanism is the tools for forecasting the economic security of the enterprise by modeling methods when changing investment support.

The ability of the management system to ensure the appropriate level of economic security of the enterprise is evidence of the correct choice of the model of its long-term growth, indicating effective management and the correct choice of development strategy. Prospective analysis of investment support, based on mathematical modeling of economic security of the enterprise, allows you to build deterministic factor models and reflect the relationship between key indicators, make forecast reports, conduct situational analysis, sensitivity analysis and determine the limits of acceptable risk. In the course of long-term analysis the tasks of finding ways to achieve goals (normative or target forecasting of economic security of the enterprise) or determining a realistically achievable goal that meets the needs of development (experimental forecasting) have solved.

Therefore, the need for forecasting based on the construction of a model that reflects the relationship between indicators of economic security of the enterprise and investment security and linking the model with the desired goal (ie assessing the effectiveness of investment through the prism of economic security).

The purpose of the study - the formation of tools for forecasting the economic security of the enterprise by modeling methods when changing investment support. The main idea of the study is that the effectiveness of the economic security of the enterprise is the main criterion for ensuring the longterm growth of the enterprise for the selected purposes, according to the determinants of investment security, within acceptable risk.

The research hypothesis is as follows:

The condition for long-term growth of the enterprise for the selected goals is the modernization of the economic security of the enterprise by integrating the principles of effectiveness of the economic security management system in the project management of investment programs of key objectives of longterm growth. 


\section{Literary review}

Economic security has derived from the basic category of national security, which considered in the research of scientists through the prism of management, economic theory, management, macro- and microeconomics, and so on. Theoretical development of economic security involves the sustainability of the socio-economic system, management of a safe trend of such development, with an indicative approach to measuring and assessing the current level within the given growth limits (Perevozova et al., 2019; Bondarenko et al., 2021; Mavlutova et al., 2021).

The development of the theory of economic security based on:

- determining the category of economic security in relation to the conditions and factors that ensure the development, efficiency of the economic system, its protection from external and internal threats (Kevin \&Warm, 2013; Bondarenko et al., 2021);

- assessment of the state of the economic system, which provides socio-economic development, protection of economic and national interests, as well as resistance to negative and destabilizing factors (Lee, 2015; Fuller, 2017);

- characteristics of the properties of the economic system, according to the reflection on the influence of determinants of the internal and external environment (Avgerou, 2008; Al-Khouri, 2014; Gruber, 2017);

- financial support of the enterprise (Altman, 1968; Lang et al., 1989; Wanjuu \& Le Roux, 2017)

- the concept of sustainable development of a complex system (Our Common Future, 1987);

- the concept of dynamic capabilities, ie the ability to create, integrate and reconfigure internal and external competencies in order to respond to a rapidly changing business environment (Teece et al., 1997);

- risk management and risk sustainability of the enterprise (Choiet al.,2017; Liubokhynets et al., 2020; Bondarenko et al., 2020).

The enterprise is seen as a complex socio-economic system that operates in an environment with perturbation parameters that distort control results (Grimsley \& Meehan, 2007; Han, 2017). To study complex socio-economic systems, it is advisable to rely on a systems approach based on the provisions of the theory of synergetics, so that it becomes possible to maximize coverage of all relationships and consequences of the decision (Fig. 1).

Fig. 1. Schemeoperation of the enterprise ascomplex socio-economic system, and threats to its activities when interacting with the environment

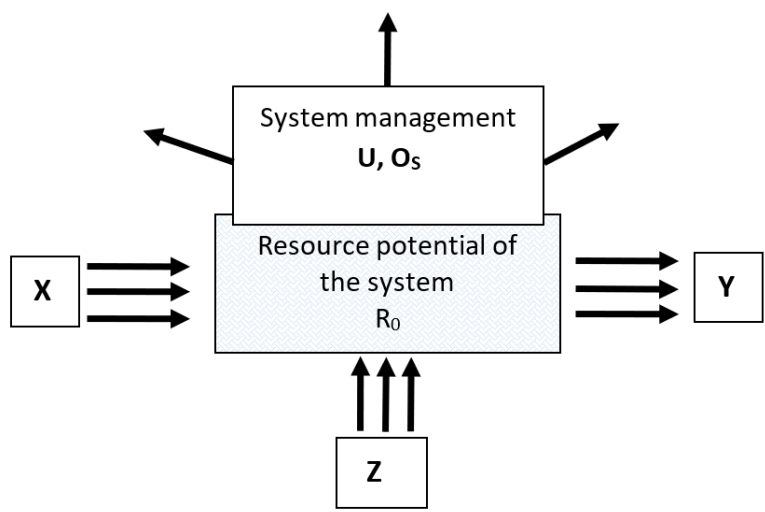

extract from the figure:

$X$-input factor parameters of the influence of exogenous nature; $Y$ - initial effective parameters of the organization of endogenous nature; $Z$ - accidental influences and perturbations of the external environment on the organization; $U$ - parameters of organization management and regulation of the impact on the environment; Os - organizational management system of the enterprise; Ro-resource potential of the enterprise

Therefore, economic security is the protection of the enterprise from unwanted changes that may occur under the influence of negative factors of the external and internal environment, provided the creation of a management system for key threat factors. In order for the company to function 
successfully, it is necessary to maintain its stability, integrity, as well as its components (personnel, information, tangible and intangible assets, finance, clientele) and, in addition, to preserve development prospects (Van Caenegem \& Skordas, 2007). Economic security of the enterprise is a complex category that contains a set of different elements for a particular enterprise at different time intervals:

- static component $\left(R_{0}\right)$ - a state of resource potential of the enterprise, which has developed as a result of the enterprise and threats of its activities in the previous period and which determines its financial and economic capabilities to achieve its strategic goal in the current period;

- dynamic component of the current period $(U)$ - the ability of the management system to manage in the face of internal and external destructive factors to achieve the goals of enterprise development $(Y)$;

- organizational management system $\left(\mathrm{O}_{s}\right)$ - a dynamic component aimed at the results of the enterprise in the future - a set of adaptive actions within the existing management system (or building a new architecture) to the action of all types of stimuli $(X, Z)$.

Thus, the general categorical understanding of economic security of the enterprise $\left(E R_{0}\right)$ can be described by the functional:

$$
E R_{0}=F\left\{\alpha R_{0} ; \beta U ; \vartheta O_{s}\right\}
$$

where $\alpha, \beta, \vartheta$ - coefficients of significance for the enterprise elements of economic security at a certain point in the study.

The basis of the resource-oriented approach to the organization of the security system of the enterprise is the idea of functioning of subject-oriented management systems. This approach will help optimize the interaction of all subsystems of the overall management system of the enterprise, on the basis of managing the economic security of the enterprise (Naylor \& Schauland, 1976; Yiu, 2008; Strobl et al., 2016). Within this study, the economic security of the enterprise is a reflection of its ability to achieve its goals based on the strategy of activities in a highly competitive environment (Chandler, 1962; Amouzesh et al., 2011). Such opportunities are due to the available resource reserve for the sustainability of the enterprise, as well as the ability of the management system to ensure the realization of the resource potential of the enterprise to achieve certain goals (Alti, 2003; Gupta \& Dhami, 2015; Holovatyi, 2014). The condition for the implementation of the mechanism management of the economic security of the enterprise is the consistency of the overall management system of the enterprise with others subject-oriented management systems (Fig. 2).

Figure 2. The triad of implementation of the mechanism of management of the economic security of the enterprise

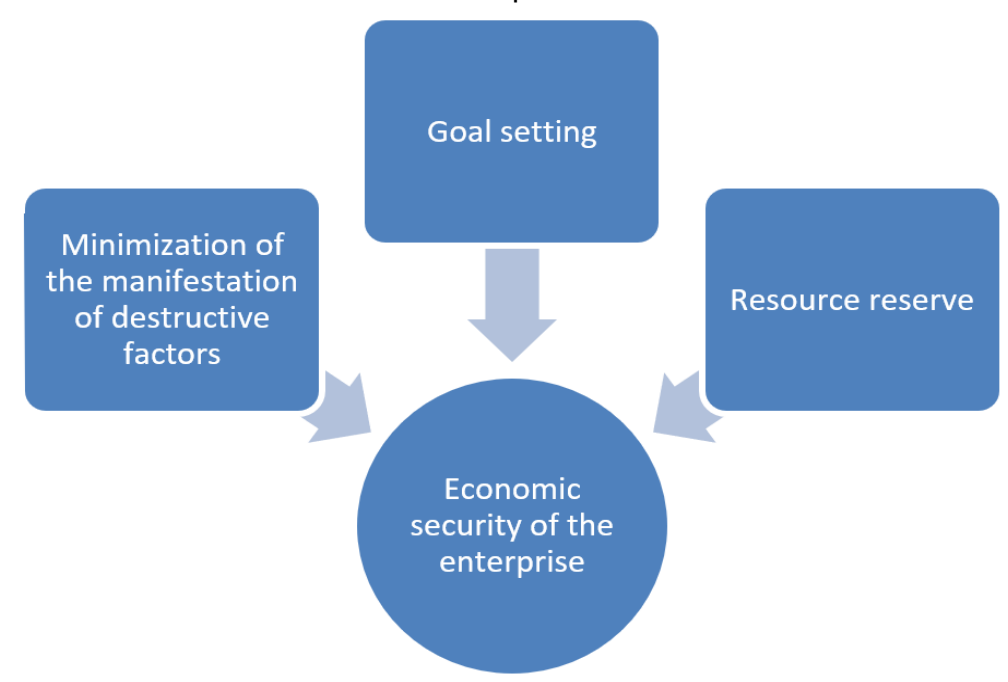

The economic security of the enterprise presupposes the consistency of the following parameters 
of managerial influence:

- goal-setting of the general management system of the enterprise with other subject-oriented management systems;

- identification and formation of a resource reserve sufficient to support the sustainable operation and development of the enterprise, on the basis of self-organization and self-preservation (system support);

- detailing and adaptation of the mechanism of the economic security system of the enterprise in relation to the action of destructive factors.

The implementation of the mechanism of management of the economic security of the enterprise requires the implementation of a proactive strategy aimed at strengthening economic security (Ivashkovskaya, 2007; Liubokhynets et al., 2020). This requires:

- to assess and regularly monitor the actual integrated indicator of economic security of the enterprise - on the basis of expert assessment (cognitive approach) or calculated on the basis of the analysis of activities for previous years (normative approach);

- to determine the margin of safety of the economic security of the enterprise by comparing the calculated actual integrated indicator with its planned value.

In this case, the margin of safety of the economic security of the enterprise can be considered the main in assessing the effectiveness of the management mechanism of the economic security of the enterprise (Hayes \& Nolan, 1974; Romanenko \& Chaplay, 2016; Sudomyr et al., 2020). The system of economic security of the enterprise is an open dynamic system that is capable under certain conditions of self-development and self-organization, which is characterized by equilibrium and unbalanced states of possible existence. At the same time, the equilibrium state of the economic security system of the enterprise allows it to exert a functional influence on the object of management. Diverse actions of external and internal threats have a negative impact on the ability to effectively use the resource potential of the enterprise (Malyarets et al., 2019). The unbalanced state of the system is a transition to a qualitatively new state. Thus, the management of the economic security of the enterprise is the direction of managerial influence on the optimal use of internal reserves of self-development and selforganization of the system in a direction consistent with the overall strategy of the enterprise (Abdullah et al 2014).

Part of the resource potential has directed to ensure the effective functioning of the economic security of the enterprise. The resource potential of the enterprise has replenished from various sources, including through investment activities. At the same time, the function of self-preservation, as a derivative of economic security, contributes to increasing the adaptive qualities and abilities of the organizational structure of the system to ensure the security of the environment by ensuring longterm growth of the enterprise for selected purposes (shaikh et al 2020). If transformational changes are required, new elements are introduced into the system on a temporary or permanent basis to perform specific tasks of protection of individual subject-oriented systems and the general management system of the enterprise.

\section{Methodology}

To achieve the goal of this study, a system of general scientific and special methods and approaches was used, in particular: general, general scientific, interdisciplinary and special research methods.

The basis of this study was the methodology of managing the project cycle of investment activities of the enterprise (Stewart \& Bennett, 1991; Minu, 2002; Komonen et al., 2006). Project management is the implementation of a comprehensive management concept that ensures the achievement of project objectives (predetermined specific result, in a timely manner and within a fixed budget) by dynamically linking business processes of the enterprise, both permanently functioning and created to obtain intermediate results. According to this methodology, investment project management processes form a project cycle, which consists of six stages: programming; identification; formulation; financing; implementation; evaluation and audit. Project Cycle Management (PCM) includes 
management processes and decision-making procedures applied throughout the project life cycle (Norton \& Kaplan, 1996; Monino, 2016). At each stage of the project cycle for the system of economic security of the enterprise have characterized by the types of threats and risks that must be taken into account in making management decisions. Projects must meet the objectives of the overall strategy of the enterprise, taking into account the objectives of functional strategies and subject-oriented systems. Investment projects must be realistic from a practical point of view, ie their goals were considered achievable given the constraints in the implementation environment and the capabilities of the enterprise subsystems involved in the implementation of projects (Minu, 2002; Smith \& Amoruso, 2006; Sagan et al., 2020 ).

PCM focuses on the active participation of stakeholders, ie all participants in the project cycle (Scott, 2004; Strang \& Sun, 2017). Stakeholder analysis involves identifying all stakeholders / organizations / institutions that may be affected by the proposed intervention (both positively and negatively), identifying and analyzing their interests, problems, potential, etc. (Rappaport, 1999; Prymush, 2013). The conclusions of such an analysis then integrated into the project plan. Logicalstructural analysis used to implement PCM, as well as other tools for analysis / evaluation of key aspects (such as problems, goals and strategies). Based on this analysis, a set of safety indicators for project implementation was determined. Each stage in the project cycle includes the main criteria for assessing the quality of performance (Gupta \& Dhami, 2015). Key documents with sound information (ie those that contain common concepts and definitions) should be developed for each stage, on the basis of which informed decisions can be made (James, 2009; Khomutenkoet al, 2019). Such indicators further serve as indicators for assessing the effectiveness of the project, and hence the ability of the economic security of the enterprise to ensure the safe operation of the enterprise, the implementation of its objectives (shahzad et al 2019).

\section{Evaluation and analysis of results}

\subsection{Characteristics of the economic security system of the enterprise with the identification of project risks of investment activities}

The basis of the overall management system should be a subsystem for managing the economic security of the enterprise. To expand the functional influence or create a new subject-oriented system, the company must strengthen the system of economic security, attracting certain resources and determining the vector of management influence on the functional basis. Graphically, the proposed architecture can be represented as a three-dimensional configuration (Fig. 3):

Figure 3. Three-dimensional configuration of the architecture of the economic security of the enterprise

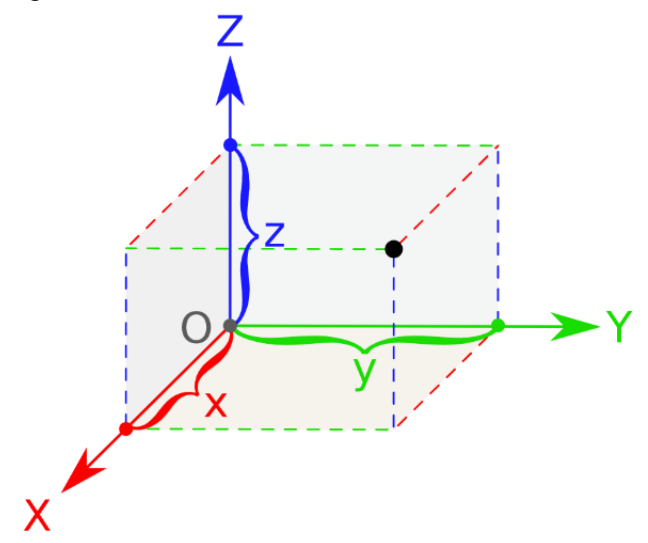

extract from the figure:

OX - objects of management (intangible intellectual assets, material, labor, financial, information resources); oY - subject-oriented management systems (economic security system of the enterprise, investment management system); OZ - management functions.

The object plane of the management system from the standpoint of the functional influence of 
control systems can be represented by a matrix that characterizes each component of the economic security system of the enterprise for a specific subject-oriented management system:

$$
E R_{i j}=\left(R_{11} \cdots R_{1 m}: \because: R_{n 1} \cdots R_{n m}\right)
$$

where $E R_{i j}$ - a generalized description of the objects of management in the system of economic security of the enterprise; $R_{i j}$ - characteristics of the object of managerial influence in the subjectoriented plane of the economic security of the enterprise; $i$ - management objects, $i=[1 ; n], i$ \{material resources, labor resources, financial resources, information resources, intangible intellectual assets\}; $j$ - management functions, $j=[1 ; m], j$ \{planning, organization, motivation, control, accounting and analysis\}.

In accordance with the principles of construction of the general architecture of the enterprise, in the context of project-oriented management, a set of characteristics has formed in relation to a specific, significant to achieve the objectives, the object. That is, each of the defined cells of the matrix reflects a certain target set of characteristics of the object of managerial influence. For example, $R_{11^{-}}$ resources of a particular type, which are used in the management system of economic security of the enterprise to perform the relevant function (planning, organization, motivation, control, accounting and analysis). The general characteristics of the system of economic security of the enterprise $\left(I\left(E R_{i j}\right)_{Y}\right)$ is an integrated indicator, which consists of a set of data about each system $\left(E R_{i j}\right)$, but, if necessary, can be structured in the resource or functional plane:

$$
I\left(E R_{i j}\right)_{Y}=\left(E R_{1} E R_{2} \quad \ldots . E R_{k}\right)
$$

where $I\left(E R_{i j}\right)_{Y}$ - generalized (integrated) characteristics of control objects in the system $Y$;

$Y$ - subject-oriented management systems, $Y=[1 ; k], Y$ - \{economic security management system, investment management system\}.

The characteristic of management objects formed in this way has structured and systematized according to management needs: for decision-making, monitoring, creation of information databases, etc. Investments have a strong impact, positive and negative, on all subsystems of the overall management system of the enterprise. Financing the implementation of investment projects is a redistribution of financial resources that occurs at all stages of the life cycle of a particular investment program. The implementation of knowledge-intensive, innovative projects has accompanied by a high degree of uncertainty. This leads to the fact that projects have usually implemented in stages. Decisions on the feasibility of further work on the project have made based on the results of each stage of the project life cycle. Problems of project implementation, as a consequence of different types of threats, have considered as risky events determined by the factors of project implementation. Depending on these factors, the loss distribution function is estimated, which, depending on the decision on the project and the requirements for its implementation can be described as follows:

- the amount of losses in case of termination of the project;

- increase project costs;

- increasing the time of project implementation, which can lead to penalties, image losses (administrative penalties) or loss of revenue.

Consider each of the possible probabilistic variants of events and their impact on the economic security of the enterprise.

1. Estimation of probabilistic losses $Y(n)$ ) (from the suspension of the project is determined by:

$$
Y(n)=\sum_{l=1}^{n-1}\left(y_{l}-c_{l}\right)+p_{n} \cdot\left(y_{n}-c_{n}\right)
$$

where: $\mathrm{n}$ - conditional serial number $\mathrm{N}$ of the project stage $(\mathrm{n}=1,2, \ldots, \mathrm{N}) ; p_{n}$ - the probability of successful completion of each stage of the project; $I$ - stages of project implementation, after which there were factors that led to the suspension of the project; $y_{n}$-costs for the implementation of the $\mathrm{n}$-th stage of the project; $c_{n}$ - possible positive result due to the capitalization or realization of the 
results of intellectual activity (partial or indirect) obtained at each stage of the project.

Reassessment of probabilities as a result of a risk event leads to a revaluation of the expected loss in the analyzed period of security assessment on the subject-oriented management system (economic security system of the enterprise, investment management system):

$$
Y\left(n, n+k, N^{n+m}\right)=\sum_{l=1}^{n+k-1}\left(y_{l}-c_{l}\right)+\sum_{l=n+k}^{N^{n+m}} P(l) \cdot \sum_{m=n+k}^{l}\left(y_{m}-c_{m}\right)
$$

where: $P(l)$ - the probability of failure of the project after I stages; If during this period the stages of the project are concluded $N^{n+m}$, starting from the $\mathrm{n}$-th, then the average expected loss due to wasted resources, estimated after the $(\mathrm{n}+\mathrm{k})$-th executed stage $\left(\mathrm{n}+\mathrm{k} \leq N^{n+m}\right)$.

$$
P(l)=\left\{\left(1-p_{l}\right) \cdot \prod_{m=n+k}^{l-1} p_{m} 1-p_{l}, l=n+k, l>n+k\right.
$$

If the funding is from external sources, then the failure of the project leads to the cessation of further funding and a reduction in incoming cash flow.

2. In the case when during the implementation of the project there is an increase in its price at some $\mathrm{n}$-th stage, the exponential law of distribution of the value of the increase can be applied:

$$
f\left(\Delta y_{n}\right)=1-e^{-\sigma_{n} \Delta y_{n}}
$$

where: $\Delta y_{n}$ - increase in price of the project at the nth stage; $\sigma_{n}$-parameter of the law of distribution of growth of expenses for the project at each $\mathrm{n}$-th stage.

The general rise in price of the project has determined by a set of root causes (rise in price of various works, services, products of suppliers for various reasons, including as a result of errors in forecasting their value, etc.). Assuming that their occurrences are independent of each other, we can assume that their number has distributed according to Poisson's law (each root cause entails some average value of the rise). The mathematical expectation of an increase in this case is equal to $1 / \sigma_{n}$.. The parameter $\sigma_{n}$. and the corresponding mathematical expectation of the increase can be defined as follows:

$$
1-e^{-\sigma_{n} y_{n}}=p_{n}^{0}
$$

where $p_{n}^{0}$ is the value of the probability with which the costs of the $\mathrm{n}$-th stage of the project are doubled. Similarly, you can specify that the cost will increase by a quarter, one and a half times, triple (if necessary).

That is, the risk of rising costs of all stages of the project, and hence the project as a whole, can be calculated by the formula:

$$
\Delta \underline{Y}=-\sum_{n=1}^{N} \frac{y_{n}}{\ln \left(1-p_{n}^{0}\right)}
$$

3. If there are circumstances that will lead to an extension of the project implementation period, the risk of rising costs of individual stages of the project, as well as the project as a whole, can be calculated by the formula:

$$
\Delta \underline{T}=-\sum_{n=1}^{N} \frac{\tau_{n}}{\ln \left(1-p_{n}^{0}\right)}
$$

where $\Delta \tau_{n}$ is the value of the delay of the $\mathrm{n}$-th stage.

If the delay in project implementation entails any losses $u$, for example, lost profits, additional costs (rent, salary, etc.), fines, etc., the average expected loss in the financial dimension is determined as follows:

$$
\Delta \underline{Y}=\Delta \underline{T} \cdot u=-\sum_{n=1}^{N} \frac{\tau_{n} \cdot u}{\ln \left(1-p_{n}^{0}\right)}
$$

The value of $u$ determined taking into account the discount rate - in accordance with the bank loan 
rate, regulatory rent on the capital of the enterprise or based on other considerations arising from the financial policy of the enterprise. Thus, the change in investment security is a key factor influencing the economic security of the organization. Investment support should be focused on strengthening and replenishing the resource reserve of the enterprise - according to the priority of goals.

\subsection{The mechanism of economic security in the system of project management of the enterprise in the optimization of interests and losses}

The target direction of enterprise development is a complex, multilevel category, which has formed under the influence of a number of objective factors in the process of coordination of subjective economic interests. One of the main properties of this category should be considered its target nature, the possibility of using as a tool to reconcile the subjective interests of potential investors and the company - the recipient of investments. The target direction of enterprise development has formed under the influence of a number of factors that reflect a set of characteristics that meet the interests of a particular type of investor.

Table 1. Target development and types of investors for an industrial enterprise

\begin{tabular}{|c|c|c|}
\hline \multicolumn{2}{|c|}{ Types of investors } & Target direction of development \\
\hline \multicolumn{2}{|c|}{ Strategic investor } & $\begin{array}{l}\text { Key goals: } \\
\text { - Achieving leading positions in the market } \\
\text { - Improving business efficiency } \\
\text { - Realization of property rights, control over the object of investment } \\
\text { Subordinate goals: } \\
\text { - expanding the sphere of influence } \\
\text { - increasing market share or entering new markets } \\
\text { - combining different parts of the production cycle, access to new resources and } \\
\text { technologies } \\
\text { - development of the enterprise, expanding its production, innovation, market, } \\
\text { financial potential. }\end{array}$ \\
\hline \multirow[t]{2}{*}{$\begin{array}{l}\text { Financial } \\
\text { investor }\end{array}$} & $\begin{array}{l}\text { Share capital } \\
\text { contribution }\end{array}$ & $\begin{array}{l}\text { Key goals: } \\
\text { - obtaining the maximum financial benefit } \\
\text { - minimizing risks } \\
\text { Subordinate goals: } \\
\text { - fast return on investment } \\
\text { - achieving a high level of return on investment } \\
\text { - increasing the level of financial performance of the enterprise } \\
\text { - obtaining additional income from the sale of shares when leaving the } \\
\text { shareholders. }\end{array}$ \\
\hline & $\begin{array}{l}\text { Contribution } \\
\text { to a specific } \\
\text { project }\end{array}$ & $\begin{array}{l}\text { Key goals: } \\
\text { - obtaining the maximum financial benefit } \\
\text { - minimizing risks } \\
\text { Subordinate goals: } \\
\text { - fast return on investment } \\
\text { - achieving a high level of return on investment } \\
\text { - increasing the level of financial performance of the enterprise. }\end{array}$ \\
\hline \multicolumn{2}{|l|}{ State } & $\begin{array}{l}\text { Key goals: } \\
\text { - increasing the level of socio-economic development of the country (region) } \\
\text { - strengthening the position of the industry in international trade; } \\
\text { Subordinate goals: } \\
\text { - transition to an innovative way of development } \\
\text { - renewal of fixed assets } \\
\text { - job creation } \\
\text { - increase of national prestige } \\
\text { - development of the enterprise, expansion of its production, innovation, market } \\
\text { potential }\end{array}$ \\
\hline
\end{tabular}

In the framework of this study, a general classification of investors by program objectives proposed, which can be applied to any enterprise, regardless of its organizational and legal form and industry 
affiliation, which includes strategic, financial investor and the state. The goals of the financial investor data differentiated (table 1).

The main interest for a financial investor may be both investments in the share capital of an industrial enterprise and investments in a separate project. Purposeful influence on key factors allows the company to improve exactly those parameters that are most important for attracting optimal investments, which allows you to use such a mechanism of interaction with investors and other stakeholders. Each target of enterprise development depends on the target tasks of selected types of business processes (internal and external) (Table 2).

Table 2 . Matrix of influence of target tasks by types of business processes on target tasks of the enterprise

\begin{tabular}{|c|c|c|c|c|c|c|}
\hline \multirow{2}{*}{$\begin{array}{c}\text { The target task of } \\
\text { enterprise } \\
\text { development }\end{array}$} & \multicolumn{5}{|c|}{ Target tasks by types of business processes } \\
\cline { 2 - 7 } & $\mathbf{C}_{1}^{v}$ & $\mathbf{C}_{2}^{v}$ & $\cdots$ & $\mathbf{C}_{j}^{v}$ & $\ldots$ & $\mathbf{C}_{m}^{v}$ \\
\hline $\mathbf{C}_{1}$ & $c_{1,1}^{v}$ & $c_{1,2}^{v}$ & $\ldots$ & $c_{1, j}^{v}$ & $\ldots$ & $c_{1, m}^{v}$ \\
\hline $\mathbf{C}_{i}$ & $c_{i, 1}^{v}$ & $c_{i, 2}^{v}$ & $\ldots$ & $c_{i, j}^{v}$ & $\ldots$ & $c_{i, m}^{v}$ \\
\hline $\mathbf{C}_{n}$ & $c_{n, 1}^{v}$ & $c_{n, 2}^{v}$ & $\ldots$ & $c_{n, j}^{v}$ & $\ldots$ & $c_{n, m}^{v}$ \\
\hline
\end{tabular}

Element $c_{i, j}^{v}$ shows the share of the j-th target $\mathbf{C}_{j}^{v}$ each of the types of business processes in solving the i-th target $\mathbf{C}_{i}$ enterprise development.

A complete description of the enterprise will give $k$ matrices of influence, the set of which forms a three-dimensional matrix impact tensor, which contains information about the consistency of the goals of the enterprise and the goals of its business processes for the selected group of stakeholders. The vector of consistency of the goals of enterprise development can be represented as:

$$
\begin{aligned}
& \qquad V_{s}=\left\{\sum_{j=1}^{m} \sum_{v=1}^{k} c_{1, j,}^{v}, \sum_{j=1}^{m} \sum_{v=1}^{k} c_{2, j}^{v}, \cdots \sum_{j=1}^{m} \sum_{v=1}^{k} c_{i, j, \cdots}^{v} \sum_{j=1}^{m} \sum_{v=1}^{k} c_{n, j}^{v}\right\} \\
& \operatorname{or}\left\{v_{s_{1}}, v_{s_{2},}, \ldots v_{s_{i}, \cdots}, v_{s_{n}}\right\} \\
& \qquad v_{S i}=\sum_{j=1}^{m} \sum_{v=1}^{k} c_{i, j}^{v} \text { shows the degree of compliance of all goals for selected }
\end{aligned}
$$
business processes to the i-th target $\mathbf{C}_{i}$ enterprises.

The effectiveness of the goals is possible only if the full consistency of the vectors, which is achieved by $\mathbf{V}_{S i}=1$. In the case when there is insufficient consistency of target vectors, partial effectiveness is possible: $. V_{S i}<1$, ie the goal of enterprise development will not be fully achieved. The situation that indicates the need for organizational transformations is that confirms the effect of functional redundancy of the enterprise $V_{S i}>1$ such a state, when the purpose and objectives of structural units intersect or duplicate each other, which leads to increased costs, reduces the efficiency and effectiveness of the enterprise, and in the worst case, leads to a conflict of interest. This situation significantly affects the state of the resource potential of the enterprise, and hence the level of its economic security.

The consistency of the vectors of the enterprise development goals according to the selected business processes gives the weighted average value of the vector elements $\mathbf{V}_{S}$ :

$$
S_{r}=\sum_{i=1}^{n} r_{i} \times v_{s_{i}}=\sum_{i=1}^{n} r_{i} \times \sum_{j=1}^{m} \sum_{v=1}^{k} c_{i, j}^{v}
$$


where $r_{i}$ weight ranking coefficient of the i-th target $\mathbf{C}_{i}$ in the total vector of the selected goals of the enterprise $\left(\mathbf{R}=\left\{r_{1}, r_{2}, \ldots, r_{i}, \ldots, r_{n}\right\}\right)$.

The consistency of the goals of enterprise development according to the selected business processes, according to the target tasks of the v-th production unit for the target tasks of the enterprise, can be represented by a matrix:

$$
\mathbf{V}_{C}^{v}=\left[\begin{array}{cccccc}
c_{1,1}^{v} & c_{1,2}^{v} & \cdots & c_{1, j}^{v} & \cdots & c_{1, m}^{v} \\
c_{2,1}^{v} & c_{2,2}^{v} & \cdots & c_{2, j}^{v} & \cdots & c_{2, m}^{v} \\
\vdots & \vdots & \vdots \cdots & \vdots & \vdots \cdots & \vdots \\
c_{i, 1}^{v} & c_{i, 2}^{v} & \cdots & c_{i, j}^{v} & \cdots & c_{i, m}^{v} \\
\vdots & \vdots & \vdots \cdots & \vdots & \vdots \cdots & \vdots \\
c_{n, 1}^{v} & c_{n, 2}^{v} & \cdots & c_{n, j}^{v} & \cdots & c_{n, m}^{v}
\end{array}\right]
$$

The vector of goals is an integrated indicator, which includes $n$ elements that have ranks, expressed by weights and, accordingly, reflect the goals of the enterprise by their ranks (significance at the moment).

The total matrix of influence of target tasks of production units (concerning internal business processes of the enterprise) on target tasks of the enterprise on the allocated business processes (taking into account interests of the allocated stakeholders) is formed by summation of all matrices of influence:

$$
\mathbf{V}_{\Sigma}=\sum_{v=1}^{k} \mathbf{V}_{C}^{v}=\left[\begin{array}{cccccc}
\sum_{v=1}^{k} c_{1,1}^{v} & \sum_{v=1}^{k} c_{1,2}^{v} & \cdots & \sum_{v=1}^{k} c_{1, j}^{v} & \ldots & \sum_{v=1}^{k} c_{1, m}^{v} \\
\sum_{v=1}^{k} c_{2,1}^{v} & \sum_{v=1}^{k} c_{2,2}^{v} & \ldots & \sum_{v=1}^{k} c_{2, j}^{v} & \ldots & \sum_{v=1}^{k} c_{2, m}^{v} \\
\vdots & \vdots & \vdots \ldots & \vdots & \vdots \ldots & \vdots \\
\sum_{v=1}^{k} c_{i, 1}^{v} & \sum_{v=1}^{k} c_{i, 2}^{v} & \ldots & \sum_{v=1}^{k} c_{i, j}^{v} & \ldots & \sum_{v=1}^{k} c_{i, m}^{v} \\
\vdots & \vdots & \vdots \ldots & \vdots & \vdots \ldots & \vdots \\
\sum_{v=1}^{k} c_{n, 1}^{v} & \sum_{v=1}^{k} c_{n, 2}^{v} & \cdots & \sum_{v=1}^{k} c_{n, j}^{v} & \cdots & \sum_{v=1}^{k} c_{n, m}^{v}
\end{array}\right] .
$$

The matrix of coordination of target tasks of production units by the target task, on the allocated business processes of the enterprise, represents summation of elements of a total matrix of influence on lines matrix $\mathbf{V}_{\Sigma}$ multiplied by a single matrix $\mathbf{E}$ :

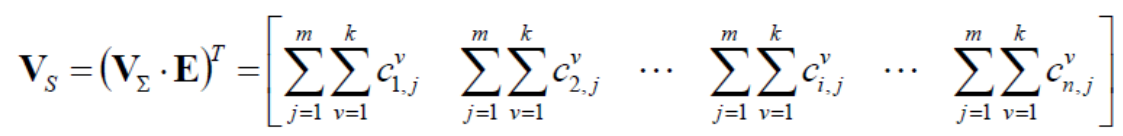

where $\mathbf{E}$ - single matrix.

To make a management decision it is necessary to have the resulting indicator of the degree of consistency of all elements (sub-goals) of the general vector of goals for the selected business processes of the enterprise:

$$
\mathbf{S}_{r}=\mathbf{V}_{S} \cdot \mathbf{R}^{T}=\left[S_{r}\right]
$$

where $S_{r}$ the only element of the matrix $\mathbf{S}_{r}$, which is an indicator of the degree of consistency of the elements of the vector of enterprise goals; $\mathbf{R}$ ranking matrix with weights (by rank of goals).

In order to ensure the effective achievement of both strategic and tactical goals of enterprise development, it is necessary to clearly define the priority areas for the selected business processes. This 
approach is most effective in the project organization of the management process, which has used in the management of investment activities.

The projects were proposed to consider both investment projects and the activities to ensure the appropriate level of economic security of the enterprise. Project management is non-cyclical and is not permanent. Therefore, the system of economic security of the enterprise in the plane of interaction with the management system of investment activities should be organized on a project basis, using specific approaches to building the overall architecture of the enterprise.

Project-oriented modeling of business processes of the enterprise involves the implementation of individual projects by structural components (economic processes), which must be implemented through subject-oriented systems of management influence.

This is possible on the basis of the implementation of the process of adaptive management, based on the definition of safe limits of long-term growth of the enterprise (Figure 4).

Fig. 4. The mechanism of adaptive management of the enterprise on the basis of formation of the adaptive and safe environment

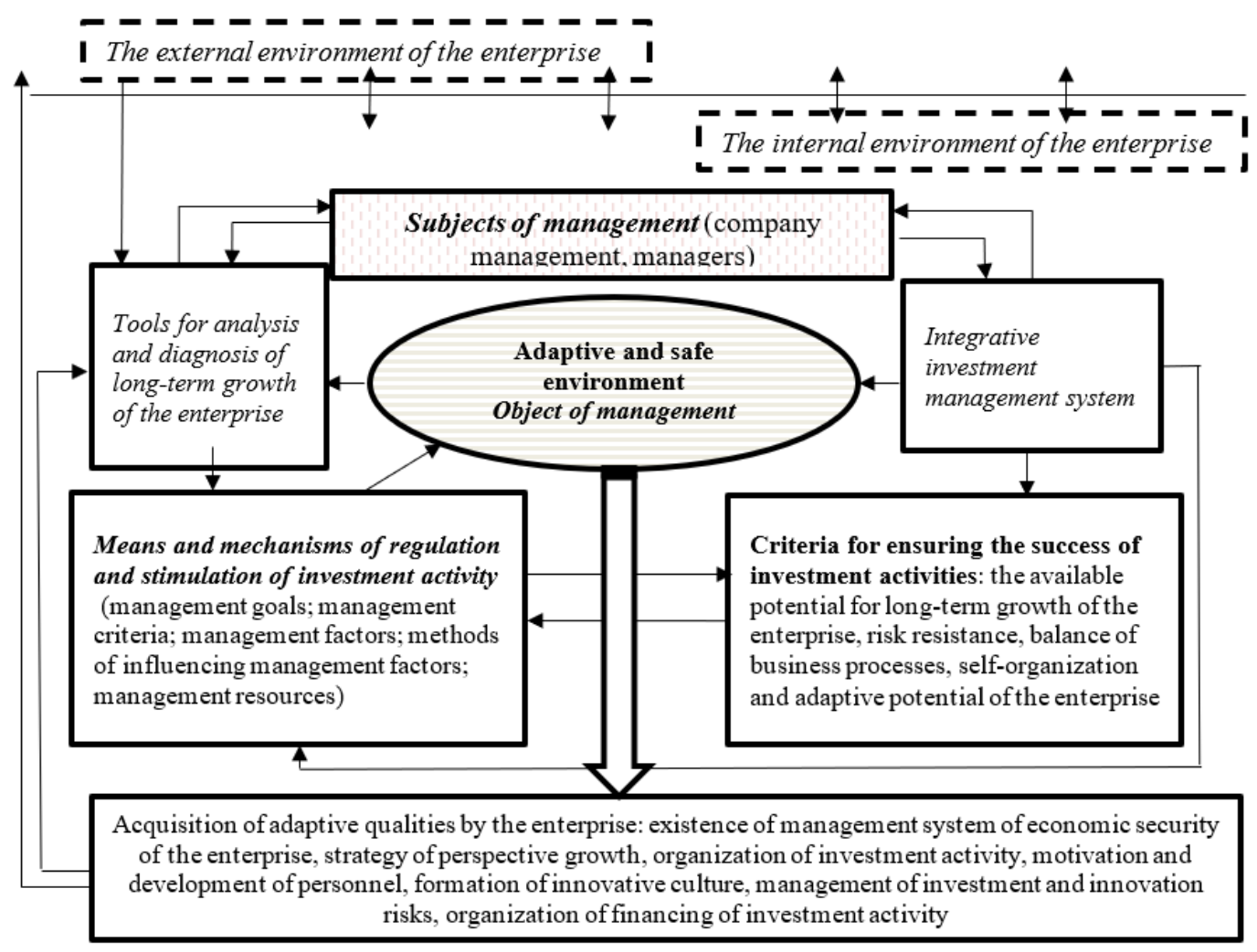

Adaptive and safe environment- a set of mutually agreed conditions of the internal and external environment of the enterprise, stimulating the creation and implementation of innovations, as well as tools and methods that promote investment activities of the enterprise and manifested in the acquisition of certain resource, financial, social qualities of adaptive nature in making changes in financial and economic activities. response to the variability of the socio-economic environment. The formation of adaptation and safety environment associated with the concentration of management activities on balancing the business processes of the enterprise, the implementation of opportunities for self-organization of socio-economic system and practical solutions to adaptation and development on an innovative basis with investment resources. The system of adaptive management should stimulate the creation of conditions for an adequate response to changes in the external and internal environment, to create additional opportunities to expand the range of selection of behavioral options in specific situations. This will allow to develop and make effective management decisions, to form strategic guidelines and goals, to develop innovative programs, to implement investment projects.

Criteria ensuring the long-term development of the enterprise within the framework of this study 
are: available resource potential, risk resilience, balanced business processes, self-organization and adaptive potential. Qualities of adaptive naturefor the enterprise, the following are distinguished: the presence of a management system of economic security of the enterprise - to determine the target vectors of development, based on the strategy promising growth; organization of investment activities; motivation and staff development, knowledge management; formation of innovation culture, investment and innovation risk management, organization of investment financing.

The mechanism of adaptive management is part of the overall management system of the enterprise, which provides influence on the factors on the state of which depends on the result of the managed object. Under the adaptive mechanism of sustainable development of the enterprise means a set of goals, methods, sequence of targeted actions to identify, assess and minimize the negative impact of external and internal factors affecting the system, resulting in the ability and additional conditions of transition from dynamic equilibrium to sustainable development .

The result of the mechanism of adaptive enterprise management has aimed at achieving economic stability, increasing investment attractiveness, stimulating innovation, which will increase competitiveness, stimulate investment and innovation development, positive changes in indicators of sustainable development of the enterprise.

\subsection{Methods for assessing the long-term development of the enterprise}

To increase the effectiveness of management decisions, an important aspect of management is the diagnosis of the stage of development of the enterprise, which will provide information for the development of appropriate adaptive measures. The procedure for finding an integrated indicator of long-term development of the enterprise presented in Figure 5.

Fig. 5. Methods for assessing the development of the enterprise

1. Selection of indicators to assess the future development of enterprises, according to development goals, development of a reference system of indicators

\begin{tabular}{|}
$\begin{array}{c}\text { 2. Determining the growth rate values of indicators, calculation of growth rate indices, their ranking, } \\
\text { comparison of the ranked series with the reference }\end{array}$ \\
3. Calculation of rank correlation coefficients \\
4. Determining the coefficient of self-organization and stage of development of the enterprise \\
5. Determining the degree of deviation of enterprise development from the goals, \\
identification of "weaknesses" of the management system
\end{tabular}

The method of assessing the stage of development of the enterprise has developed in order to:

- monitoring aimed at the rapid identification of critical parameters and determining the position (stage) of the enterprise in the cycle of self-development;

- analysis designed to identify the control parameters of the system capable of self-organization that need adjustment;

- management, ie the development of optimal management influences depending on the identified during the monitoring and analysis of the stage of development and control parameters of the system;

- forecasting based on determining the position of the enterprise in the cycle of self-development and the expected transition to the next stage.

The system of indicators (standard) for assessing the stage of development of the enterprise presented in table 3. 
Table 3 Ranking of growth rates of indicators of the target direction of enterprise development

\begin{tabular}{|l|c|}
\hline \multicolumn{1}{|c|}{ Indicator } & Rank \\
\hline Net profit & 1 \\
\hline The cost of export products & 2 \\
\hline Net income from sales of products & 3 \\
\hline Production volume & 4 \\
\hline Current assets & 5 \\
\hline Equity & 6 \\
\hline Fixed capital investment & 7 \\
\hline Intangible assets & 8 \\
\hline Total assets & 9 \\
\hline Salary fund & 10 \\
\hline Average annual staff & 11 \\
\hline The cost of production & 12 \\
\hline Payables & 13 \\
\hline Receivables & 14 \\
\hline
\end{tabular}

The result is a reference system of indicators that reflects the optimal conditions for the operation and development of the enterprise. The established relations have the following logical interpretation. For a successfully operating enterprise has characterized by outpacing the growth rate of profit over the growth of sales revenue, which, in turn, exceeds the growth rate of assets. This pattern indicates an effective sales policy of the enterprise. Regarding the ratio of the growth rate of sales revenue and the growth rate of borrowed capital, a significant increase in borrowed funds must be provided by the income received to repay debt service obligations (interest on loans and borrowings, etc.) and the principal amount unpaid debts. In addition, it has recommended to assess the adequacy of cash balances to cover priority payments (accounts payable). The condition for the development of the enterprise is the excess of the growth rate of exported products over the growth rate of revenue, as this is a guarantee of expanding the market and increasing the competitiveness of enterprise products. The outstripping dynamics of current assets and equity determines the growth of liquidity and financial independence, and the rate of investment in fixed capital over the growth rate of total capital of the enterprise - indicates an increase in capital investment, and thus increase development potential. Regarding the ratio of growth rates of equity and debt capital, from the point of view of creditors and investors, equity should grow faster, which minimizes the risks of work. The financial manager of the enterprise can bet on the predominant growth of borrowed capital when choosing sources of business financing, It is important to anticipate the dynamics of intangible assets over the growth rate of total assets, which indicates the intellectualization of enterprise capital, and thus provides capacity building for innovative development. It is also natural to assume that gross profit grows faster than the number of employees and thus increases productivity. The duration of the repayment of receivables should be reduced, which characterizes the effective management of current assets. An important condition for the financial security of the enterprise was a balanced duration of the turnover of receivables and payables. The average maturity of receivables should be less than the maturity of accounts payable, ie the company first receives cash to repay liabilities from third parties,

Table 4 presents the degree of density of the relationship between the actual and reference ratio of indicators and the corresponding options for choosing managerial influences depending on the value of the coefficient of self-organization. 
Table 4. Scale of values of the coefficient of self-organization of enterprises from the standpoint of options for managerial influence

\begin{tabular}{|c|c|c|c|c|}
\hline $\begin{array}{l}\text { Intervals of values } \\
\text { of the coefficient } \\
\text { of self- } \\
\text { organization of } \\
\text { the enterprise }\end{array}$ & $\begin{array}{l}\text { The degree of } \\
\text { connection } \\
\text { between the } \\
\text { reference and the } \\
\text { actual ratio of } \\
\text { indicators }\end{array}$ & $\begin{array}{l}\text { Stage of self- } \\
\text { organization }\end{array}$ & $\begin{array}{c}\text { Developmen } \\
\text { t zone }\end{array}$ & $\begin{array}{l}\text { Choice of management } \\
\text { influence options }\end{array}$ \\
\hline$[0.0-0.2)$ & Missing & $\begin{array}{l}\text { Construction } \\
\text { of a new } \\
\text { model of self- } \\
\text { organization } \\
\text { of subsystems }\end{array}$ & Bifurcations & $\begin{array}{l}\text { Purposeful self- } \\
\text { organization, building a } \\
\text { new system capable of self- } \\
\text { organization }\end{array}$ \\
\hline$[0.2-0.4)$ & Weak & $\begin{array}{l}\text { Transitional } \\
\text { stage }\end{array}$ & Critical & $\begin{array}{l}\text { Purposeful self- } \\
\text { organization, without } \\
\text { reliance on self- } \\
\text { organization of subsystems }\end{array}$ \\
\hline$[0.4-0.7]$ & Medium & $\begin{array}{l}\text { Dynamic } \\
\text { equilibrium }\end{array}$ & Normal & $\begin{array}{l}\text { Self-organization and } \\
\text { purposeful influence are } \\
\text { equally related }\end{array}$ \\
\hline [0.7 - 1.0] & Strong & $\begin{array}{l}\text { Dynamic } \\
\text { equilibrium }\end{array}$ & Reference & $\begin{array}{l}\text { The advantage of the } \\
\text { processes of self- } \\
\text { organization of subsystems, } \\
\text { if necessary - their } \\
\text { regulation, aimed at } \\
\text { returning the system to } \\
\text { equilibrium }\end{array}$ \\
\hline
\end{tabular}

The ratio of self-organization processes and managerial influences depends on the value of the selforganization coefficient $K_{s o}$ thus: with increasing coefficient the level of self-organization of enterprise subsystems increases. Each stage of the process of self-organization corresponds to a certain value of the coefficient $K_{s o}$. Thus, the enterprise in the cycle of self-development can be in the following zones: bifurcation, critical zone, normative and reference. To move the company to the stage of dynamic equilibrium, it is necessary to develop a set of optimal management influence that will contribute to the realization of the potential of self-organization of the enterprise and achieve a trajectory of development as close as possible to the ideal. The level of self-organization of the enterprise makes it possible to assess the adaptive potential of the enterprise as the ability to adapt to the action of all types of stimuli within the existing management system (or building a new architecture). It is proposed to define the adaptive potential of the enterprise as the difference between the resource potential of the enterprise for the studied period and the locally achieved level of self-organization from the unit (distance to the reference stage):

$$
\left\{R P=1-\sum_{i=1}^{n} \quad K_{s o_{i}} \frac{1-\underline{K_{s o_{i}}}}{n} P_{\text {adapt }}=1-\left(R P-K_{s o_{i}}\right)\right.
$$

where $P_{\text {adapt }}$ - the adaptive potential of the enterprise; $R P$ - resource potential of the enterprise; $\frac{1-K_{s o_{i}}}{n}$ - the speed of enterprise development, as the ability of the management system to manage in the conditions of internal and external destructive factors, to achieve the goals of enterprise development; $K_{S_{i}}{ }^{-}$the arithmetic mean of the coefficient of self-organization within the existing management system; and $i$ - the study period, $\mathrm{n}$ - the number of years.

At the same time, the calculated value of adaptive potential based on the indicator of selforganization is a dynamic indicator that can act as a criterion for assessing the effectiveness of the management system of the enterprise to ensure the long-term growth of the enterprise for selected purposes. If the adaptive potential of the enterprise has realized, the level of self-organization increases, which indicates the effectiveness of the economic security system of the enterprise - the formed management system is able to bring the enterprise to the stage of dynamic equilibrium. The 
main condition for the effective functioning and development of enterprises is to ensure an appropriate level of sustainability. Understanding the stability of the enterprise as a system, the ability to maintain itself, to exist and develop dynamically, it is important to identify parameters in the presence of disturbances that disrupt the normal course of business processes.

According to the results of the study, the crisis of the current stage of enterprise development is due to a very low level of risk resilience. The derivative of this is the imbalance of business processes of enterprises and a low level of self-organization and, consequently, adaptive capacity. Accordingly, enterprises have a very low level of resource potential. Therefore, the tasks of balanced management of investment resources are especially relevant in a period of deep financial crisis and acute shortage of working capital of enterprises.Adaptive management should be aimed at ensuring the fullest use of the resource potential of the enterprise in order to achieve innovative change.

\section{Conclusion}

In this study the main aspects of modeling the economic security of the enterprise when changing the investment security are considered. The effectiveness of the economic security of the enterprise is distinguished by the main criterion for ensuring the long-term growth of the enterprise for the selected purposes, according to the determinants of investment security, within acceptable risk. A variant of the economic security model of the enterprise has been developed and is being implemented. The model provides for the implementation of the process of adaptive management, based on the definition of safe limits of long-term growth of the enterprise. The system of indicators (standard) for an estimation of a stage of development of the enterprise is presented. The analysis shows that the ratio of self-organization processes and managerial influences depends on the value of the self-organization coefficient. Proposed as a dynamic indicator of long-term growth of the enterprise for the selected purposes - the calculated value of adaptive potential based on the indicator of self-organization. This indicator can serve as a criterion for assessing the effectiveness of the management system of the enterprise in relation to the project management of economic security of the enterprise in the implementation of investment programs of key goals of long-term growth of the enterprise.

\section{References}

1. Alghamdi, A., Thanoon, M., Alsulami, A. "Toward a Smart Campus Using loT: Framework for Safety and Security System on a University Campus", Advances in Science, Technology and Engineering Systems Journal, vol. 4, no. 5, pp. 97-103 (2019).

2. Al-Khouri, A. M. (2014). Digital identity: Transforming GCC economies. Organization \& Management. 16(2), 184-194. DOI: https:// doi.org/10.1080/14479338.2014.11081981.

3. Alti, Aydogan (2003). How sensitive is investment to cash flow when financing is frictionless? The Journal of Finance, 58(2), 707-722.

4. Altman, E.I. (1968). Financial Ratios, Discriminant Analysis and the Prediction of Corporate Bankruptcy. Journal of Finance, 589 - 609.

5. Amouzesh, N., Moeinfar, Z. \& Mousavi, Z. (2011). Sustainable Growth Rate and Firm Performance: Evidence From Iran Stock Exchange, International Journal of Business and Social Science, 23(2) (2011) 249-255.

6. Avgerou, C. (2008). Information systems in developing countries: a critical research review. Journal of Information Technologies, 23, 133-144. DOI: https://doi.org/10.1057/palgrave.jit.2000136.

7. Babenko, V., Perevozova, I., Mandych, O., Kvyatko, T., Maliy, O., Mykolenko, I. (2019). World informatization in conditions of international globalization: Factors of influence. Global Journal of Environmental Science and Management, 5 (Special issue), pp. 172-179. http://dx.doi.org/10.22034/gjesm.2019.05.SI.19

8. Bondarenko S., Halachenko O., Shmorgun L., Volokhova I., Khomutenko A. \& Krainov V. (2021). The 
Effectiveness of Network Systems in Providing Project Maturity of Public Management. TEM Journal. 10(1), 358-367, DOI: 10.18421/TEM101-34

9. Bondarenko, S., Ivanchenkova, L., Okhrimenko, O., Zybareva, O., Karpitskaya, M., Huz, M. (2020). Risk Management of Enterprise Restructuring Strategy. International Journal of Advanced Research in Engineering and Technology. 11(5). 14-25.

10.Bondarenko, S., Tkach, I., Drobotov, S., Mysyk, A., Plutytska, K. (2021). National Resilience as a Determinant of National Security of Ukraine. Journal of Optimization in Industrial Engineering. 14 (1), Winter \& Spring. 111-117.

11.Chandler, A. D. (1962), Strategy and Structure: chapters in the history of the industrial enterprise. Cambridge: MIT Press, $463 \mathrm{p}$.

12.Choi T. M., Chan H. K., \& Yue X. (2017). Recent development in big data analytics for business operations and risk management. IEEE transactions on cybernetics, 47(1), 81-92. URL: https://ieeexplore.ieee.org/abstract/document/7378465 DOI: 10.18421/TEM101-45.

13.Fuller, C. S. (2017). The perils of privacy regulation. The Review of Austrian Economics, 30(2), 193214. DOI: https:// doi.org/10.1007/s11138-016-0345-0.

14.Grimsley, M. \& Meehan, A. (2007). E-Government information systems: Evaluation-led design for public value and client trust. European Journal of Information Systems, 16, 134-149. DOI: doi:10.1057/palgrave.ejis.3000674.

15.Gruber, H. (2017). Innovation, skills and investment: A digital industrial policy for Europe. Journal of Industrial and Business Economics, 44(3), 327-342. DOI: https://doi.org/10.1007/s40812-0170073-x.

16.Gupta, A. \& Dhami, A. (2015). Measuring the impact of security, trust and privacy in information sharing: A study on social networking sites. Journal of Direct, Data and Digital Marketing Practice, 17(1), 43-53. DOI: https://doi.org/10.1057/ dddmp.2015.32.

17.Han, D. (2017). The Market Value of Who We Are: The Flow of Personal Data and Its Regulation in China. Media and Communication, 5(2), 21-30. DOI: http://dx.doi.org/10.17645/mac.v5i2.890.

18. Hayes, R .H. \& Nolan, R.L. (1974). What kind of corporate modeling functions best, Harvard Business Review, 3 (52), 102-112.

19. Holovatyi, M. (2014). Multiculturalism as a means of nations and countries interethnic unity achieving. Economic Annals-XXI, 11-12, 15-18.

20.Ivashkovskaya, I. V., \& Yanhel, D. O. (2007). The organization's life cycle and the aggregate growth rate. Korporatyvnye fynansy, 4, 97-110.

21.JAMES, J. (2009). Sharing Mechanisms for Information Technology in Developing Countries, Social Capital and Quality of Life. Social Indicators Research, 94, 43-59. DOI: https://doi.org/10.1007/s11205-008-9335-3.

22.Kaplan, R.S. \& Norton, D.P. (1996). Using the Balanced Scorecard as a Stretegic Management System. $75-85$ p.

23.Kevin, M.M. \& Topel, R.H. (2013). Some Basic Economics of National Security American Economic Review. (103). 508-511.

24.Khomutenko, A., Mishchenko, A., Ripenko, A., Frum, O., Liulchak, Z., \& Hrozovskyi, R. (2019). Tools of the neuro-fuzzy model of information risk management in national security. International Journal of Engineering and Advanced Technology, 8(6), 4526-4530.

25.Komonen, K., Kortelainen, H., Räikkonen, M. (2006). An asset management framework to improve longer term returns on investments in the capital intensive industries. In Proceedings of the 1st World Congress on Engineering Asset Management, WCEAM, Gold Coast, Australia, 11-14 July 2006; pp. 418-432.

26.Lang, L.H.P., Stulz, R.M. \& Walkling R.A. (1989). Managerial performance, Tobin's Q, and the gains from successful tender offers Journal of Financial Economics. 24 (1). 137-154. doi: 10.1016/0304- 
405X(89)90075-5.

27.Lee, H. Endress (2015). Chapter 3 - Scarcity, Security, and Sustainable Development Sustainable Economic Development. Resources, Environment and Institutions. 49-66. doi: 10.1016/B978-0-12800347-3.00003-0.

28.Liubokhynets, L., Rudnichenko, Y., Dzhereliuk, I., Illiashenko, O., Kryvdyk, V., Havlovska, N. (2020). Methodological foundations of flexible management and assessing the flexibility of an enterprise economic security system. International Journal of Scientific and Technology Research, 9 (3), pp. 4616-4621.

29.Malyarets, L.M., Babenko, V.O., Nazarenko, O.V., Ryzhikova, N.I. (2019). The Modeling of Multicriteria Assessment Activity in Enterprise Management, Int. J Sup. Chain. Mgt, vol. 8, no. 4, pp. 9971004. http://ojs.excelingtech.co.uk/index.php/IJSCM/article/view/3342

30.Mavlutova, I., Babenko, V., Dykan, V., Prokopenko, N., Kalinichenko, S. \& Tokmakova, I. (2021). Business Restructuring as a Method of Strengtening Company's Financial Position. Journal of Optimization in Industrial Engineering, 14(1), 129-139.

http://dx.doi.org/10.22094/JOIE.2020.677839

31.Miller, D. A., \& Friesen, P. H. (1984). Longitude study of the corporate life cycle. Management science, 30, 1161-1183.

32.Minu, Hemmati. (2002), Multi-stakeholder processes for governance and sustainability : beyond deadlock and conflict / with contributions from Felix Dodds, Jasmin Enyati, and Jan McHarry, London, Earthscan Publications Ltd London. 327 p.

33.Monino, J.-L. (2016). Data Value, Big Data Analytics, and Decision-Making. Journal of Knowledge Economy, 1-12. DOI: https://doi.org/10.1007/s13132-016-0396-2.

34.Naylor, T.H. \& Schauland, H. (1976). A Survey of Users of Corporate Planning Models, Management Science, 9(22), 927-937.

35.Norton, D. \& Kaplan, R. (1996). The Balanced Scorecard: translating strategy into action. Harvard: Business Press, $221 \mathrm{p}$.

36.Our Common Future (1987). United Nations World Commission on Environment and Development. Oxford, UK : Oxford University Press, 57-59.

37.Perevozova, I., Daliak, N. \& Babenko, V. (2019). Modeling of Financial Support for the Competitiveness of Employees in the Mining Industry. CEUR Workshop Proceedings, vol. 2422, pp. 444-454. URL: http://ceur-ws.org/Vol-2422/paper36.pdf

38.Prymush, Yu. S. (2013). Estimation of the influence of external factors on the life cycle of construction enterprises. Ekonomichnyy prostir. 77, 201-213.

39.Rappaport, A. (1999). Creating Shareholder Value: a Guide for Managers and Investors. Free Press, $432 \mathrm{p}$.

40.Romanenko, Y. O., \& Chaplay, I. V. (2016). Marketing communication system within public administration mechanisms. Actual Problems of Economics, 178(4), 69-78.

41.Sagan, O., Yakovleva, S., Anisimova, E., Balokha, A., \& Yeremenko, H. (2020). Digital didactics as a new model in the theory of education. Revista Inclusiones, 7 num Especial, 193-204.

42.Scott, J. (2004). Measuring dimensions of perceived e-business risks. Information Systems and eBusiness Management, 2(1), 31-55. DOI: https://doi.org/10.1007/s10257-003-0026-y.

43.Shahzad, B., Awan, K. M., Abdullatif, A. M., Lali, M. I., Nawaz, M. S., Ayesha, U., \& Khan, M. (2019). Quantification of productivity of the brands on social media with respect to their responsiveness. IEEE Access, 7, 9531-9539.

44.Shaikh, A., \& Alghamdi, A. (2020). loT, smart environments and interdisciplinary applications for technology management and sustainable development. International Journal of technology management \& sustainable development, 19(3). 
45.Smith, G. \& Amoruso, A. (2006). Using real options to value losses from cyber attacks. Journal of Digital asset Management, 2(3-4), 150-162. DOI: https://doi.org/10.1057/palgrave.dam.3650033.

46.Stewart, B. \& Bennett, G. (1991). The Quest for Value: a Guide for Senior Managers. NY: Harper Collins Publishers, $223 \mathrm{p}$.

47.Strang, K. D. \& Sun, Z. Ann. (2017). Big Data Paradigm: What is the Status of Privacy and Security? Annals of Data Science, 4(1), 1-17. DOI: https://doi.org/10.1007/s40745-016-0096-6.

48.Strobl, Andreas, \& Kronenberg, Christopher (2016). Entrepreneurial networks across the business life cycle: the case of Alpine hospitality entrepreneurs. International Journal of Contemporary Hospitality Management,(28) 6, 1177-1203, https://doi.org/10.1108/IJCHM-03-2014-0147.

49.Sudomyr, S., Niziaieva, V., Lutay, L., Prodanova, L., Havryliuk, O., \& Sherstyukova, K. (2020). Methods And Techniques Of Motivation Of Subjects Of Regional Economy For Innovative Improvement. International Journal of Scientific \& Technology Research, 9 (3), 1196-1200.

50.Teece D., Pisano G. \& Shuen A. (1997). Dynamic Capabilities and Strategic Management. Strategic Management Journal, 18(7), 509-533

51.Van Caenegem, B. \& Skordas, T. (2007). Community research activities in secure and trustworthy ICT infrastructures. Telecommunication Systems, 35(3-4), 89-97. DOI: https://doi.org/10.1007/s11235-007-9043-3.

52.Wanjuu, L. \& Le Roux, P. (2017). Economic Institutions and Economic Growth: Empirical Evidence from the Economic Community of West African States. South African Journal of Economic and Management Sciences, 20(1), 1607-1618. DOI: https://doi.org/10.4102/sajems.v20i1.1607.

53.YIU, C.Y. (2008). A conceptual link among facilities management, strategic management and project management. Facilities, 26, 501-511. doi/10.1108/02632770810914262/full/html. 